\title{
Assessing the Function of Palaeolithic Hearths: Experiments on Intensity of Luminosity and Radiative Heat Outputs from Different Fuel Sources
}

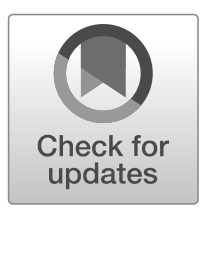

\author{
Sally Hoare ${ }^{1}$ \\ Published online: 10 January 2020 \\ (C) The Author(s) 2020
}

\begin{abstract}
Assessing the function of Palaeolithic hearths is a key research issue that can benefit from the application of experimental archaeology when examining whether the behaviourally related purposes of fire, e.g. heat, light and cooking, could be correlated with combustion features in the archaeological record. Not all species of wood and types of fuel burn the same way. Variability exists in the amount of ash and smoke produced, along with differences in speed of burning and outgoing light and heat. This paper examined the light and heat properties of nine different types of fuels (eight individual species of wood and fresh bone) by assessing intensity of luminosity and radiative heat outputs using a lux metre and thermal imaging camera. Results show that there is considerable variation between bone and wood in terms of light and heat output and between the individual species of wood. In order to assess whether heat efficiency may vary seasonally, experiments were performed overnight and repeated at ambient air temperature ranges of 11 to 13 and 0 to $3{ }^{\circ} \mathrm{C}$. Results show that in the current data set fuels that emit lower to intermediate heat outputs could be more efficient at colder temperatures in terms of warmth. This represents a preliminary step forward towards attributing behaviourally relevant functions such as light and heat to Palaeolithic combustion features with regard to fuel selectivity.
\end{abstract}

Keywords Experimental archaeology $\cdot$ Palaeolithic fire $\cdot$ Heat transfer $\cdot$ Fuel selectivity . Light $\cdot$ Heat

Electronic supplementary material The online version of this article (https://doi.org/10.1007/s41982-01900047-z) contains supplementary material, which is available to authorized users.

Sally Hoare

S.A.HOARE@LIVERPOOL.AC.UK

1 Department of Archaeology, Classics and Egyptology, University of Liverpool, Liverpool L69 3BX, UK 


\section{Introduction}

Fire is suggested to be one of the most important technological advancements of the Homo genus due to the many benefits that its use and control affords in terms of human adaptation, e.g. light, heat, cooking, defence against predators, modification of material culture and the environment and colonisation of the northern latitudes (Bentsen 2014; Brown et al. 2009; Gowlett 2006; Roebroeks and Villa 2011; Wrangham and Carmody 2010). Even with these benefits and their implications concerning the evolution of firerelated human behaviours, little is currently known surrounding the circumstances by which fire use arose and became important as a major human adaptation. Over recent years, the benefits of foraging in fire-prone environments by early hominins as a stimulus for the initial uptake of fire has been put forward (Herzog et al. 2016; Hoare 2019), Parker et al. 2016; Pruetz and Herzog 2017). Two of the most obvious and immediate benefits of fire are light and heat, and in fact, light and heat, with regard to warmth, are both benefits that can be experienced from the close association of humans and wildfires and by foraging in recently burned areas in any environmental setting. In terms of human behaviour, light is essential for the extension of daylight hours, whilst heat is essential for warmth, cooking and modification of resources such as lithic raw materials through heat treatment (Brown et al. 2009; Blasco et al. 2016; Carmody and Wrangham 2009; Goldberg et al. 2012; Gowlett and Wrangham 2013; Preece et al. 2006). Examining when and in which contexts these various uses and benefits of fire arose in the archaeological record can represent a means whereby many aspects of firerelated human behaviours can potentially be understood in an evolutionary context, e.g. earliest evidence for heat treatment of lithic raw materials in the African Middle Stone Age (Brown et al. 2009; Mourre et al. 2010; Porraz et al. 2013).

Examining the remains and function of Palaeolithic hearths is therefore a key research issue that may contribute towards identifying some of the past behaviours surrounding early human uses of fire and fuel. More specifically, the identification of materials used for fuel via micro or macro remains from combustion features can provide information archaeologically on local environments, the types of fuel used and fuel management strategies (Carrión et al. 2010; Pryor et al. 2016; Henry and Théry-Parisot 2014; Théry-Parisot 2001, 2002a, b; Vidal-Matutano et al. 2017). Identifying materials used for fuel in the archaeological record may also provide information on other important behaviourally relevant functions relating to hearth activity if the combustion properties of a fuel could be determined to provide enough benefit for a particular purpose. Delhon (2018) highlights the importance of the many socio-cultural factors that influence fuel use in the ethnographic record and stresses that, at some point, choice is always a factor when it comes to domestic hearths. It is further suggested by Delhon (2018) that identifying situations where selection of wood (whether size, species, vegetal association or phenotypic characteristics) is probable could provide a means to utilise charcoal assemblages as palaeoethnological proxies. White et al. (2017) state that the ability to maximise light and heat would be beneficial to Upper Palaeolithic hunter-gatherers, and in fact, this ability would be beneficial to all Palaeolithic populations, especially those at the mid-to-northern latitudes where the effects of seasonality on ambient temperature and length of daylight hours are most pronounced. Moreover, heat and light could have importance for the occupation of caves. It is suggested by Aldeias (2017) that 
whilst heat and light are the automatic outcomes of any fire, identifying whether they were the intended purpose is problematic, as these are behaviours that leave no discernible sedimentary signature. It is further suggested that testing for differences in the luminosity properties of different types of fuels experimentally could produce results which might then be used to attribute some degree of probability as to whether light was the likely intended purpose of fire or not.

\section{Ethnoarchaeology and Fuel Selection Criteria}

A recent paper by Henry et al. (2018) highlights the complexity of fuel selection criteria in northern boreal forest groups by examining fuel use amongst the Evenks and Athabascans of East Siberia and North America. Henry et al. (2018) suggest that ethnoarchaeological data can be used as an analytical framework to re-evaluate assumptions suggesting either that prehistoric hunter-gatherers had a purely opportunistic behaviour towards fuel governed by environmental constraints or that they were practising taxonomic selection in response to practical reasons. These authors demonstrate that both behaviours can coexist within the same fuel management system, though they are dependent on other contextual factors, e.g. combustion structure, camp location, activity and season. They also caution against the notion of 'good' or 'bad' fuels and suggest that good or bad fuels simply relate to the way in which fuels are used and perceived for different purposes. These authors suggest that the data speaks of additional research on the characterisation of the combustible properties of fuels of different natures, their states and sizes to better understand past combustion processes.

The ethnographic record shows that amongst contemporary northern latitude huntergatherers, the use of different types of fuel can vary according to both task and sometimes on a seasonal basis (Henry et al. 2018; Shaw 2008, 2012; Steelandt et al. 2013; Théry-Parisot 2002a, b). Research concerning selection for specific burning properties of different types of fuels, in relation to seasonality, amongst contemporary hunter-gatherer populations is sparse. However, it does provide some examples of seasonal changes in fuel selection criteria based on thermal qualities and duration of burning (Shaw 2008, 2012; Steelandt et al. 2013). For example, amongst the Inuit of West Coast Nunavik, the selection for Salix in the fall due to its long duration of heating has been shown (Steelandt et al. 2013), whereas the Ingalik prefer Picea in the winter due to its superior thermal properties relative to Populus and Salix (Théry-Parisot 2002a, b). A further example comes from Henry et al. (2018) where amongst the Athabascans, the genus Populus is considered a good smoking fuel, but is a bad heating fuel due to its low heat output. However, many of these examples are anecdotal, and our knowledge of the potential of both seasonal variation and selection of fuel for specific burning properties in relation to task is currently limited. Whilst the ethnographic record highlights the range of factors influencing fuel use and choice, it also provides some examples of selection of fuel based on burning properties, suggesting this could also be of importance with regard to hearth function.

\section{Previous Experiments}

Previous investigations of Palaeolithic uses of fire via experimentation have focused on purposeful thermal alteration of artefacts (Bennett 1999; Brown et al. 2009; Schmidt 
et al. 2013; 2016), incidental thermal alteration of sediments (Aldeias et al. 2016; Canti and Linford 2000; March et al. 2014), artefacts in relation to hearth proximity (Aldeias et al. 2016) and human activities on hearths/campfires (Mallol et al. 2013; Miller et al. 2010). Numerous experiments have been conducted concerning the combustion properties of fuels. Much is known regarding the combustion properties of wood and bone as a fuel in terms of temperatures, the taphonomy of wood charcoal (Dussol et al. 2017; Julia et al. 2014) and factors influencing choices of fuel outside of taxonomic selection, e.g. distance of procurement (Théry-Parisot 2002a, b). Previous experiments regarding the combustible properties of wood as fuel have focused on combustion temperatures in relation to moisture content, differences in duration of burning and flame height between seasoned, green and drift woods and identification of the latter in the archaeological record (Henry and Théry-Parisot 2014; Théry-Parisot et al. 2010; ThéryParisot and Henry 2012; Théry-Parisot 2001; 2002a, b; Vidal Matutano et al. 2017). Regarding the use of bone as a fuel, many experiments have been conducted which demonstrate the superior quality of fresh bone in terms of durability of flame in comparison to wood, and how the selection of bone at some Palaeolithic sites could relate to the more expedient need for fuel in more temporary camps (Costamagno et al. 2005; Mentzer 2009; Théry-Parisot and Costamagno 2005; Théry-Parisot et al. 2005; Théry-Parisot 2002a, b).

Most previous experiments (regardless of the objectives) report combustion temperatures of the fire from the types of fuel used. However, most species of wood and bone will produce combustion temperatures necessary for most activities (Théry-Parisot et al. 2005). The experimental work of Théry-Parisot et al. (2005) demonstrates that the duration of flame in fresh bone fires is much longer than that of wood and that bone also produces heat transfer in the form of convection and radiation, but not conduction. Théry-Parisot and Thiebault (2005) demonstrated, under standardised laboratory conditions, that the flame height of Pinus is much higher than that of Quercus, and that Pinus sylvestris produces much more active, durable flames. The production of more active flames in Pinus is due to its molecular composition and resin content, terpene hydrocarbons and the specific density of the wood. It is suggested that these properties are common in coniferous woods, i.e. softwoods. Previous experiments are, however, limited, in that they do not quantify the differences in outgoing heat and light between different wood species and fresh bone. Combustion temperatures vary significantly but are not linked to heat transfer via convection, conduction and radiation, which are the fundamental processes by which light and heat are transferred to the surrounding environment. Little is currently known with regard to the light and heat properties of different sources of fuels and although other factors can influence heat transfer, e.g. hearth shape and changes in wind speed/direction, the combustion properties of individual types of fuel may also be important in this regard and could potentially determine hearth function, should variation in light and/or heat be the objective.

Examining the combustion properties of different types of fuel (e.g. bone, wood, animal dung or lignite) with regard to their thermal transfer of energy may provide further means to examine aspects of Palaeolithic hearth/fire function and fuel selection criteria. The only previous experiments regarding heat transfer have focused on conduction from a heat source or actual fire to underlying sediments (e.g. Aldeias et al. 2016), and those of Théry-Parisot (2001) who examined thermal transfer of energy in relation to hearth function and task. This study will further examine whether 
the transfer of energy via radiation (i.e. warmth and light) from fire varies according to different types of fuel (i.e. fresh bone and wood) and whether variation exists between individual species of wood. These experiments are intended to provide a preliminary step forward in examining the outgoing heat and light properties of fuel in terms of fuel selectivity and Palaeolithic hearth function.

\section{Combustion Properties of Fuels and Transfer of Heat}

The combustion properties of different types of fuels are complex (Théry-Parisot et al. 2010). In terms of wood, they depend not only on species (density and chemical composition) but also on the physiological state of the wood, i.e. calibre and rate of humidity (Théry-Parisot et al. 2010). A common measure of fuel efficiency used to evaluate the heating properties of different types of fuel is calorific value. The calorific value, or heating value, specifies the amount of energy that develops during the complete combustion of a sample of fuel with a given mass and is usually measured in joules using a calorimetric bomb (Telmo and Lousada 2011). The calorific value of wood can be expressed as higher heating value (HHV) at a constant volume (dry basis), or low heating value (LHV) at constant pressure (wet basis). The lower heating value (wet basis) is generally considered to be the most practical measure of energy content, as the moisture content is evaporated during the burning process which also requires energy (Telmo and Lousada 2011). Radiant heat is the transfer of heat from a fire to the surrounding environment via electromagnetic waves. Radiation is the dominant mode of heat transfer during fires and can be emitted by hot surfaces as well as flames, i.e. glowing versus flaming fires (Williams 1982). Outgoing radiant heat flux, in general, depends on several factors, which include the temperature of the emitting material, the size/height of the flames or surface and the emissivity of the surface. The emissive power $E$ of a flame is the energy emitted per unit time per unit flame. Measurements of radiant heat flux can be expressed by the formula $q=\varepsilon \sigma T 4$, where $\varepsilon$ is the flame emissivity, $\sigma$ is the Stefan-Boltzmann constant $\left(5.67 \times 10-11 \mathrm{~kW} / \mathrm{m}^{2} \mathrm{~K} 4\right), T$ is the flame radiation temperature $(\mathrm{K})$ and $E$ is the flame emissive power $\left(\mathrm{kW} / \mathrm{m}^{2}\right)$. Light is transferred by similar processes to that of heat. However, there are a number of variables that may result in differences in the luminosity properties of different types of fuel, which include the chemical composition of the fuel and also the density of the wood (e.g. Théry-Parisot and Thiebault 2005).

\section{Materials and Methods}

\section{Experimental Design}

Light and heat are emitted in the form of electromagnetic waves resulting from the combustion of fuel during the fire. Fuel combustion produces thermal energy, which in turn is transferred to the surrounding area via the mechanisms of either convection, which is the transfer of heat through air currents, or radiation, which can include oxidation of fuel during the combustion process. Light is transferred via electromagnetic radiation only, which includes visible light produced by the fire and other forms of light in the infrared range which are not visible to the human eye (Figs. 1 and 2(a)). The 


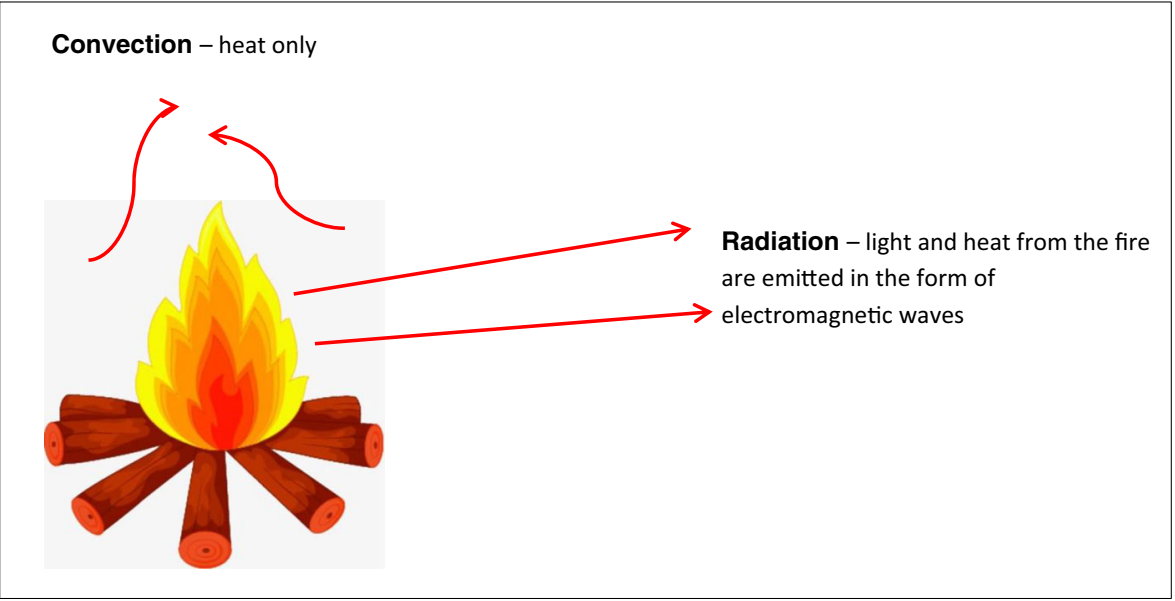

Fig. 1 Transfer of light and heat from a hearth. Heat is emitted by convection and radiation, whereas light is emitted by radiation only

main objectives of these experiments were to test whether differences in the light and radiative heat properties of different types of fuels exist and as to whether these differences are significant enough to potentially affect fuel selectivity in the Palaeolithic. The second objective was to test whether changes in ambient temperature

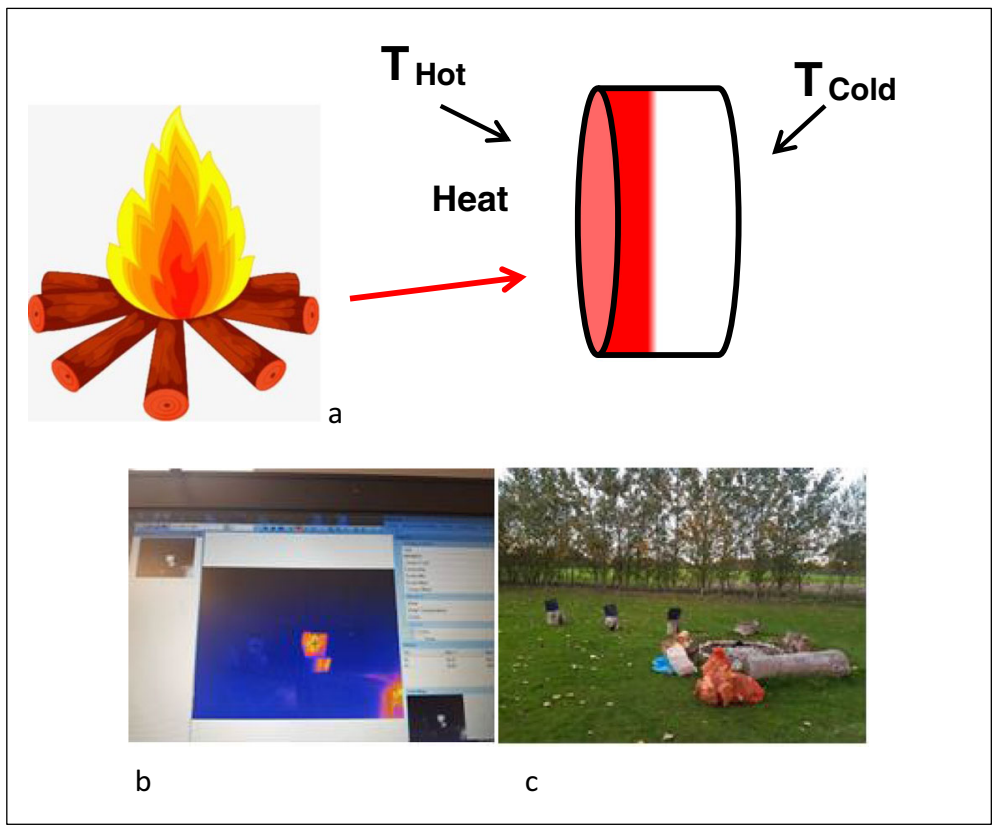

Fig. 2 Diagram showing how outgoing heat from a fire is absorbed by a body (a). The outgoing radiative heat is absorbed onto the surface only and does not penetrate. Images of the setup of the black cards relative to an experimental fire (b) and a representative thermal image (c) demonstrating how the outgoing heat from the fires was measured using the thermal imaging camera and software 
Table 1 List of genera used in the experiments. References refer to the occurrence of these genera at a range of European Middle and Upper Palaeolithic sites based on charcoal assemblages

\begin{tabular}{ll}
\hline Genus & References \\
\hline Betula & Marquer et al. (2010); Uzquiano (2014) \\
Picea & Uzquiano (2014); Cichocki et al. (2014) \\
Quercus & Badal et al. (2012); Uzquiano (2014) \\
Pinus & Marquer et al. (2010); Badal et al. (2012); Uzquiano (2014) \\
Larix & Beresford-Jones et al. (2010) \\
Alnus & Haesaerts et al. (2010) \\
Fraxinus & Uzquiano (2014) \\
Fresh bone & Villa et al. (2002); Théry-Parisot et al. (2002a); Yravedra and Uzquiano (2013) \\
\hline
\end{tabular}

could further affect choices of fuel with regard to their heat properties, i.e. seasonality or between warmer and colder periods. The aim is not to produce a dataset of good or bad fuels. All fires regardless of the type of fuel used will produce light and heat. The aim here is to examine how differences in the combustion properties of fuel, in relation to light, heat and duration of burning, could potentially be exploited for different tasks.

\section{Field Experiments}

All the experiments were designed and conducted by the author and took place in an open-air setting during October 2018 and February 2019 using eight species of wood (Betula pendula, Fraxinus excelsior, Picea abies, Larix decidua, Fagus sylvatica, Pinus sylvestris, Alnus glutinosa and Quercus robur, and fresh bone, Capreolus capreolus). The woods were selected from genera identified across a range of European Middle and Upper Palaeolithic sites (see Table 1 for list of genera and references). Each individual experiment used $35 \mathrm{~kg}$ of seasoned dried wood (logs) and fresh bone, plus a further $5.5 \mathrm{~kg}$ of seasoned dried logs of silver birch added to the bone fire. The combustion temperature of fresh bone is much higher than that of wood, and bone fires cannot be started without at least a $15 \%$ ratio of wood to begin the combustion process (Théry-Parisot et al. 2005). The fuel was added $7 \mathrm{~kg}$ at a time every $15 \mathrm{~min}$ for a period of $1 \mathrm{~h}$ and $15 \mathrm{~min}$. The moisture content of each log was measured using a Valiant FIR421 moisture metre. The total was then averaged by the number of logs used in each experiment. The experimental fires had basal configurations of 1-m and 30 -cm diameters. K-type thermocouples were used to measure the temperatures of the fires and duration of burning: two to measure the temperatures of the flames at $10 \mathrm{~cm}$ above the surface and two to measure surface temperatures of the fires. The thermocouples were set at regular intervals in pairs (centre of the fire and at $25 \mathrm{~cm}$ from the centre), and data was recorded using an automated data logger at 5-min intervals for the duration of the experiments. Twenty-seven experiments were conducted in total on the 1-m and 30-cm diameter campfire deposits: nine 1-m diameter fires using $35 \mathrm{~kg}$ of fuel at ambient temperatures of 11 to $13^{\circ} \mathrm{C}$, and then repeated using the same fuel types at 0 to $3{ }^{\circ} \mathrm{C}$. To provide external validity to these data, a further nine experiments were conducted at $0{ }^{\circ} \mathrm{C}$ on the smaller $30-\mathrm{cm}$ diameter campfires using $7 \mathrm{~kg}$ of fuel to 
examine whether smaller amounts of fuel would yield similar results as the larger fire experiments. All lux and radiative heat measurements were examined in relation to the duration of flame and temperature of the fire.

To control for the potential effects of external variables on the results, ambient temperature, wind speed and humidity measurements were taken every 10 min using a handheld Kestrel 2000 anemometer so these measurements could then be correlated with the temperature, lux and radiative heat data. The same amount, deposit size and arrangement (pyramidal stacking) of the fuel were used between the experiment types. The time taken to record all measurements was approximately $2 \mathrm{~min} 40 \mathrm{~s}$. The same sequence of measurements was followed for each experiment: radiative heat, followed by lux, followed by ambient temperature, wind speed and humidity.

\section{Radiative Heat}

In order to measure the radiative heat outputs of the different fuel sources, a thermal imaging camera and software was used. The camera was an Expert Thermal Q1, which has a temperature range between 0 and $250{ }^{\circ} \mathrm{C}$. Measurements were taken every $10 \mathrm{~min}$ at distances of 1,2 and $3 \mathrm{~m}$ from the fire (measurements were taken at different distances to account for differences in group size around fires, i.e. Binford's drop zone). Capturing outgoing radiative heat from a fire in the way a human body would experience it is no easy task. However, matte black is known to provide a highly absorbing surface in terms of outgoing radiative heat transfer. At each 1-m interval, squares of black card, $50 \times 50 \mathrm{~cm}$, were used to absorb the outgoing radiative heat from the fire, and these were set at heights of $1 \mathrm{~m}$ to represent people when sitting around a fire (see Fig. 2(b, c)). Continuous measurements were started 10 min after lighting the fire and were stopped at each interval at the point at which the fire died down. The camera was set up at the same point for each experiment and placed on a tripod. Spot points were pre-set on each card before the experiments were started (see also Fig. 2(c)).

\section{Luminosity}

The measurements were taken an ISO-TECH ILM-01 handheld lux metre. Measurements were taken every $10 \mathrm{~min}$ at the same distances of 1,2 and $3 \mathrm{~m}$ from the fire as the radiative heat. As above, the measurements were started 10 min after lighting the fire and were stopped at each interval when the lux metre recorded $1 \mathrm{~lx}$. Experiments were conducted overnight to remove any possible interference from daylight on the lux metre, and the fires were started each night when the lux metre recorded 0 in all directions from the fire.

\section{Results of $35 \mathrm{~kg}, 100-\mathrm{cm}$ Diameter Fire Experiments}

\section{Combustion Temperatures and Duration of the Fire Experiments}

The combustion temperatures of both the flames and surfaces of the fires were found to vary significantly between experiments. Peak temperatures and durations are presented 
in Tables 2, 3 and 4 for each of the experiments. The most significant differences in combustion temperatures of the flames are apparent between the different size deposits and most likely relate to the amount of fuel used. Similar to the results of Théry-Parisot et al. (2005) and Bentsen (2014), it was found here that the higher temperatures correlate to larger amounts of fuel used. Temperatures in excess of 900 to $1000{ }^{\circ} \mathrm{C}$ were regularly recorded for both the flames and some surface temperatures in the $35-\mathrm{kg}$ experiments, whereas temperatures of the $7-\mathrm{kg}$ fires were much lower and ranged between 500 and $800{ }^{\circ} \mathrm{C}$. There was no significant relationship between fuel type and combustion temperatures in relation to either the surface or flame. Notable variation was recorded between each experiment, especially for the surface temperatures. The differences in surface temperature between some of the experiments may be the result of weather conditions. Rain was experienced on some afternoons prior to the experiments being conducted, and the ground was wetter relative to other experiments. Variation in fuel loads on or around the thermocouples may also account for some of the differences. Differences were nevertheless observed in the duration of the peak temperatures and the duration of the fires between the individual fuel types, which are listed in Tables 2, 3 and 4. Some fuels, e.g. Picea and Betula, have relatively short durations of burning whilst others, e.g. fresh bone, Quercus and Fraxinus, are characterised by long, slow burning. Similar to the results of previous experiments, fresh bone has by far the longest duration of burning and the longest duration of flame.

\section{Lux Values}

Wind speed was the only external variable found to affect the results. In this case, only two experiments were affected: the 11 to $13{ }^{\circ} \mathrm{C}$ Pinus experiment (an increase in wind speed correlated with a reduction in lux values between 50 and $100 \mathrm{~min}$ ), and the 0 to $3{ }^{\circ} \mathrm{C}$ Fraxinus experiment, in which a sudden increase in wind speed adversely affected the experiment after $50 \mathrm{~min}$, and the experiment was then abandoned.

The lux values, which include the average duration of lux for each experiment and also peak lux and duration, are presented in Table $5\left(11\right.$ to $\left.13{ }^{\circ} \mathrm{C}\right)$ and Table $6(0$ to $3{ }^{\circ} \mathrm{C}$ ). Lux values are also plotted in Fig. 3 (d) and (e). Across all experiments, at both ambient temperature ranges, duration of average lux values at 1-m distance relates to the duration of flame intensity, whereas peak lux values and duration at $1 \mathrm{~m}$ generally correlate with duration of higher temperatures of the fires/flames and higher radiative heat measurements. The lux values across each experiment showed considerable variation and can be classified as high (60-68 lx), intermediate (20-35 lx) or low (412 lx). The highest lux values were recorded for Fraxinus and Betula, whereas the lowest values were recorded for Quercus, Alnus and fresh bone. The other species of wood (Fagus, Pinus, Larix and Picea) showed intermediate values (see Fig. 3(c)). Durability of light/heat was estimated by taking peak lux values and the duration of those values for both lux and radiative heat in relation to the durability of flame. Fraxinus gave the longest duration of luminosity at consistently higher values than the other types of fuel, followed by Fagus, Larix and Pinus. Fresh bone and Quercus also had substantial duration of luminosity but at much lower values. The shortest duration of luminosities was observed for Betula, Picea and Alnus. With distance, duration of average and peak lux values are shorter than at $1 \mathrm{~m}$ and both further decreased with distance across all experiments. As would be expected, fuels that emitted the highest 


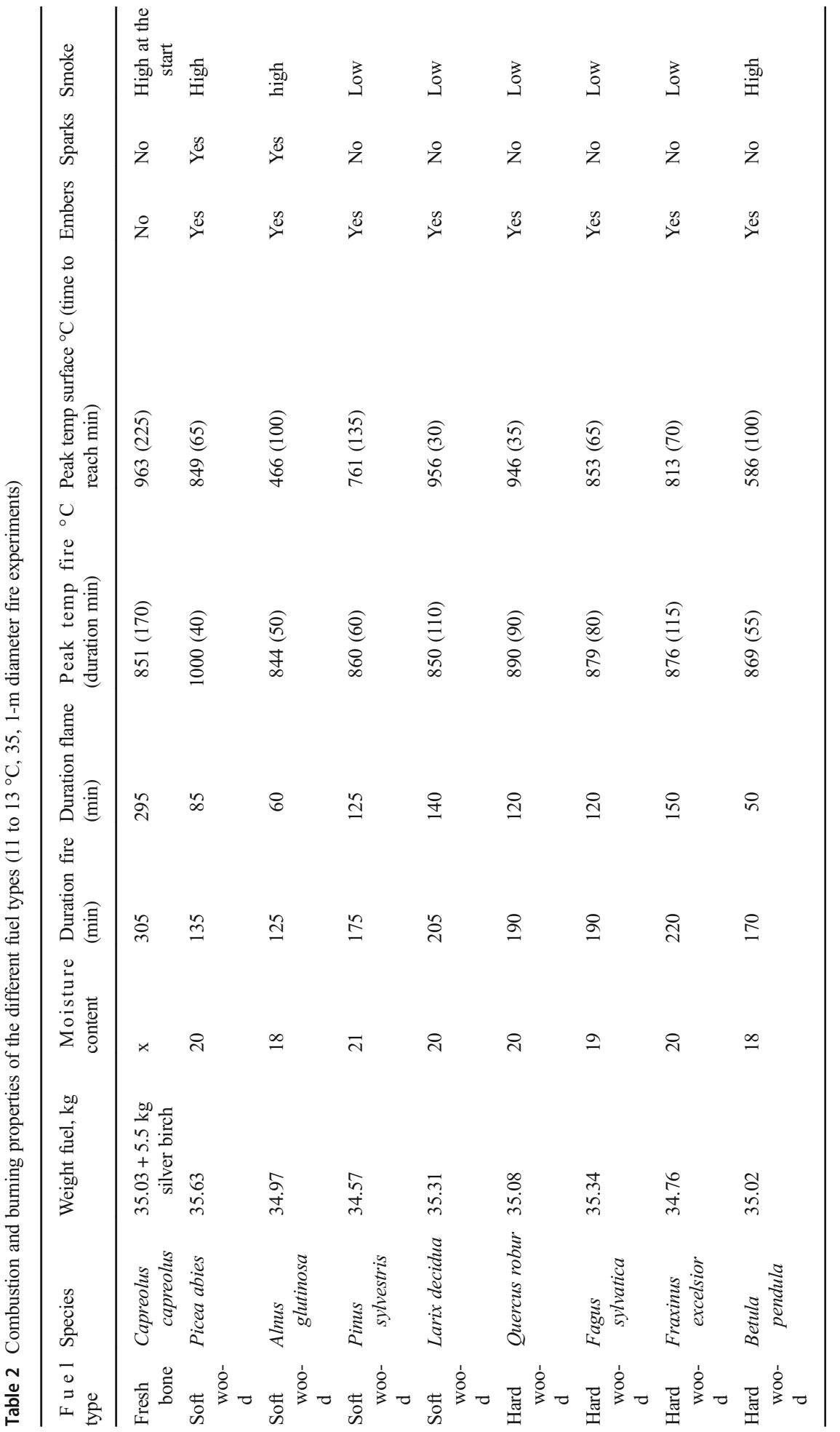




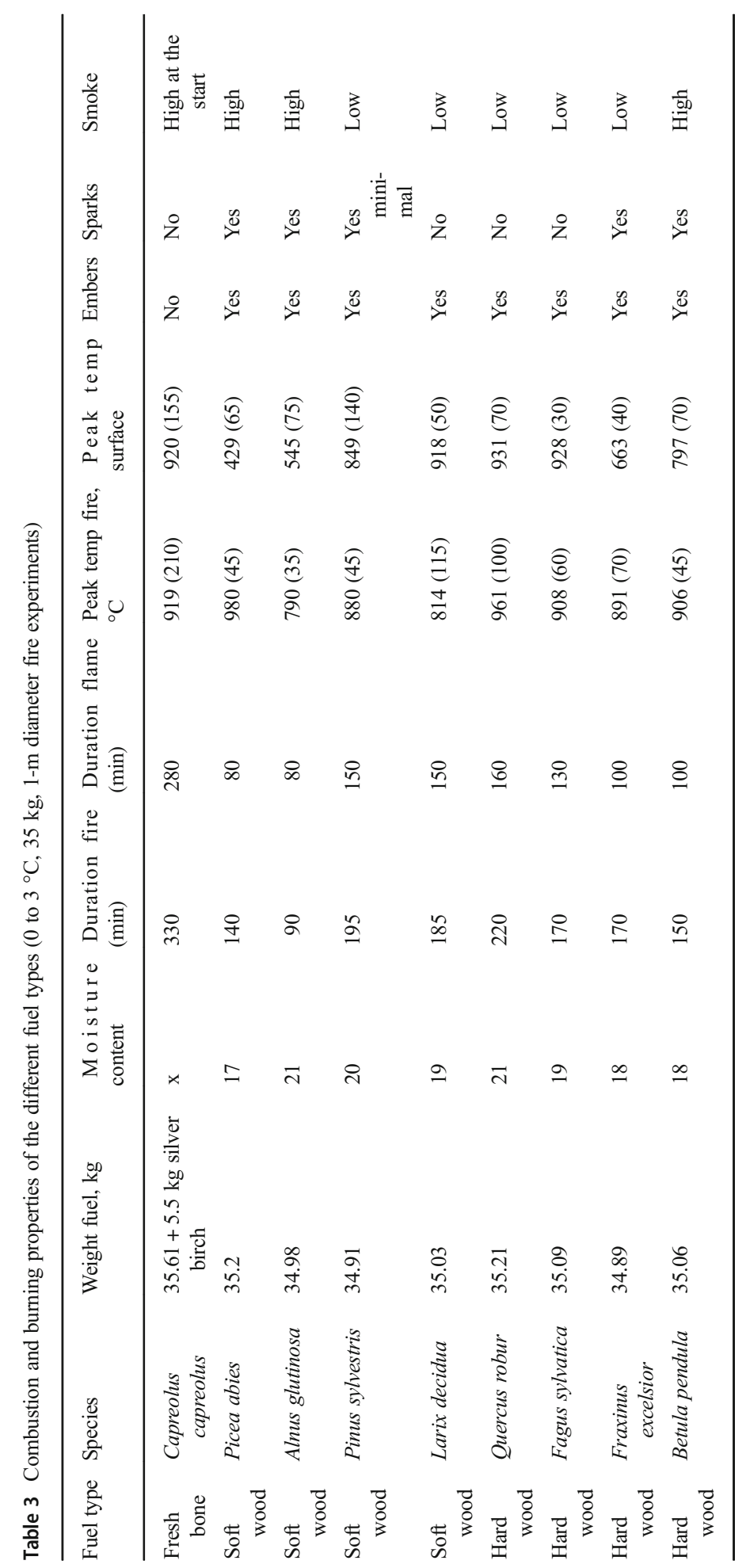




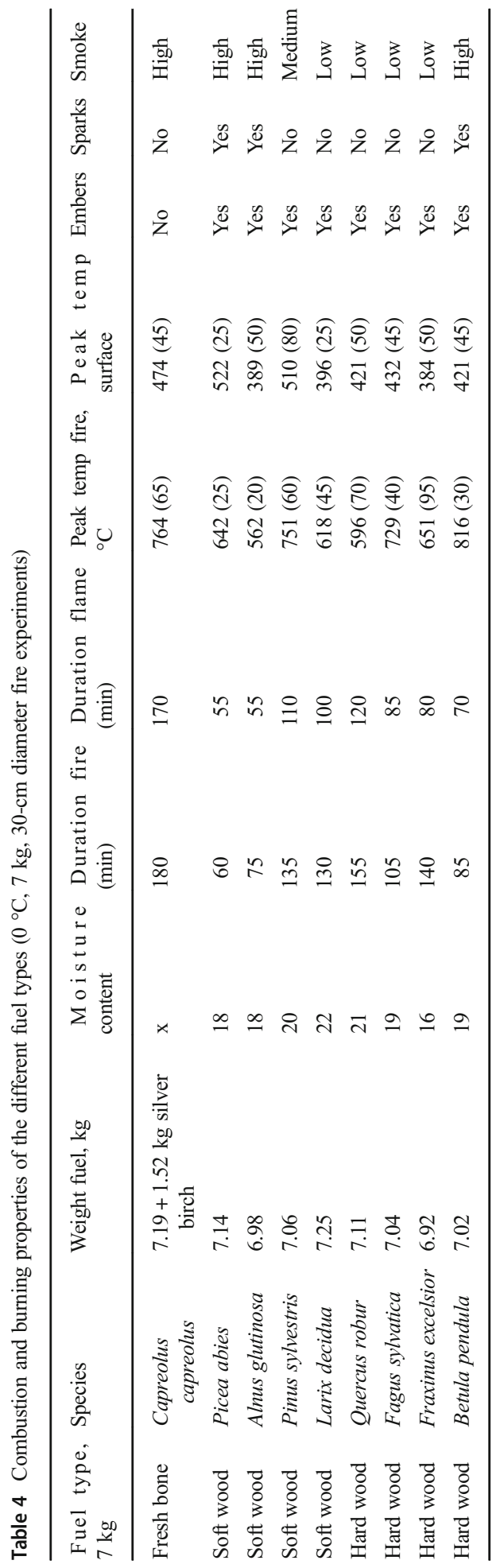


luminosities at $1 \mathrm{~m}$ also emit the highest luminosities at distance from the fire, e.g. Fraxinus and Betula. Although, at $3 \mathrm{~m}$ from the fire, very few fuels emit any significant lux values other than Fraxinus (data in Supplementary Material).

At ambient temperatures of 0 to $3{ }^{\circ} \mathrm{C}$, the results, although somewhat variable compared with the first set of experiments, do not differ substantially (see the 'Combustion Temperatures and Duration of the Fire Experiments' section and Table 3). The highest lux values were again recorded for Fraxinus and Betula, whereas the lowest values were recorded for Quercus, Alnus and fresh bone. The other species of wood (Fagus, Pinus, Larix and Picea) again showed intermediate values (see Fig. 3(d)). The results of the Fraxinus experiment at lower ambient temperatures, however, should be considered unreliable after 50 min due to the influence of significantly higher wind speeds during this experiment, which resulted in a much shorter duration of burning and eventual abandonment of this experiment. Results were also similar to the first set of experiments at distance.

\section{Radiative Heat Measurements}

In general, radiative heat measurements above ambient temperature have a longer duration than the lux values, as embers also emit a source of heat and continue to do so after the flames of a fire die down. Bone fires do not create a source of embers, so radiative heat is thus linked more to the duration of the actual fire and intensity of flame. Like the lux values, average radiative heat measurements were variable across the experiments and ranged from 18.5 to $32{ }^{\circ} \mathrm{C}$, with average durations of 70 to $270 \mathrm{~min}$. At 1-m intervals, peak temperatures range from 21.6 to $52{ }^{\circ} \mathrm{C}$, with these temperatures lasting from 30 to $200 \mathrm{~min}$. Average temperatures at $2 \mathrm{~m}$ distances from the fires were 14 to $19.8^{\circ} \mathrm{C}$, with durations of 50 to $120 \mathrm{~min}$. Peak temperatures also ranged between 16 and $22^{\circ} \mathrm{C}$, with durations of 20 to $60 \mathrm{~min}$. At $3 \mathrm{~m}$ results, save for the Picea fire, recorded temperatures barely exceeded ambient temperature by more than 1 to $2{ }^{\circ} \mathrm{C}$.

Similar to the lux data, the radiative heat measurements were classified as high, intermediate or low. Some fuels such as Betula and Fraxinus emitted very high temperatures in excess of $50{ }^{\circ} \mathrm{C}$, for up to 30 to $70 \mathrm{~min}$ of the total duration, even at $1 \mathrm{~m}$ distances from the fire. Temperatures then either reduced more rapidly as the flames and embers burned out (e.g. Betula) or reduce more gradually, e.g. Fraxinus. Other fuel types such as Larix, Picea and Pinus maintained intermediate (ca. 37 to $39^{\circ} \mathrm{C}$ ) more constant heat across the experiments, whilst fresh bone, Fagus, Quercus and Alnus emit lower values (ca. 22 to $32{ }^{\circ} \mathrm{C}$ ). Fuels that emitted the longest duration of radiative heat are fresh bone, Quercus, Larix, Pinus, Fagus and Fraxinus. The shortest durations were observed for Alnus, Picea and Betula. Alnus also yielded the lowest radiative heat measurements.

At colder temperatures $\left(0\right.$ to $\left.3{ }^{\circ} \mathrm{C}\right)$, the results were variable especially in relation to duration of heating; for example, the Quercus and fresh bones fires were $30 \mathrm{~min}$ longer than the 11 to $13^{\circ} \mathrm{C}$ experiments, and the Larix and Fagus were both shorter despite the same amount of fuel being used. Figure 3 (e) and (f) show the radiative heat measurements for both experiments. Although variation was noted in the duration of the experiments at 0 to $3{ }^{\circ} \mathrm{C}$ and differences were recorded between average and peak radiative heat measurements between the experiments, the overall results were similar to the first, in that two species of wood, Betula and Fraxinus, emitted exceptionally high radiative heat measurements with average peak values of 49 and $50{ }^{\circ} \mathrm{C}$. The other fuels examined all emitted significantly lower radiative heat measurements relative to Betula and Fraxinus. 


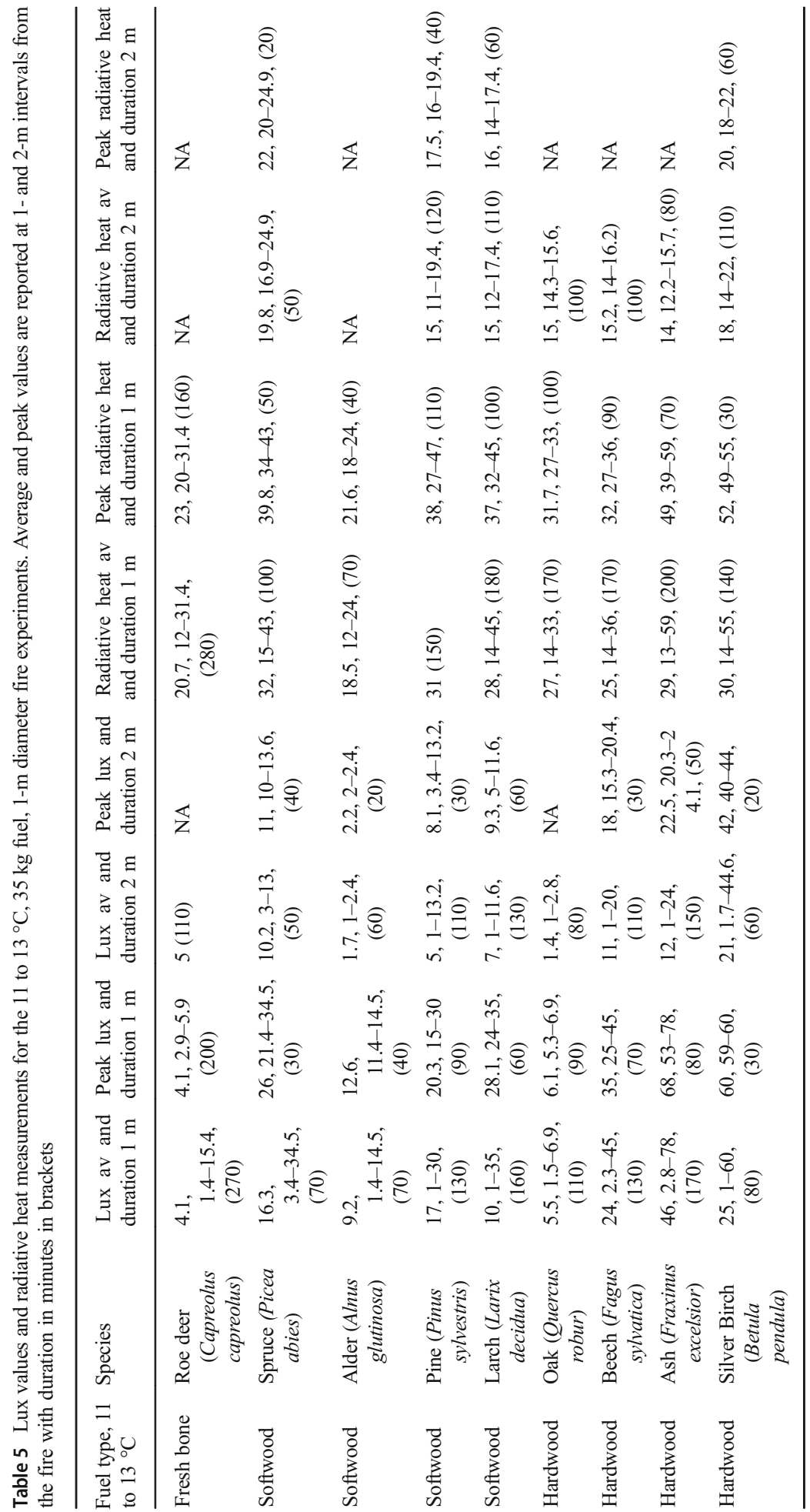




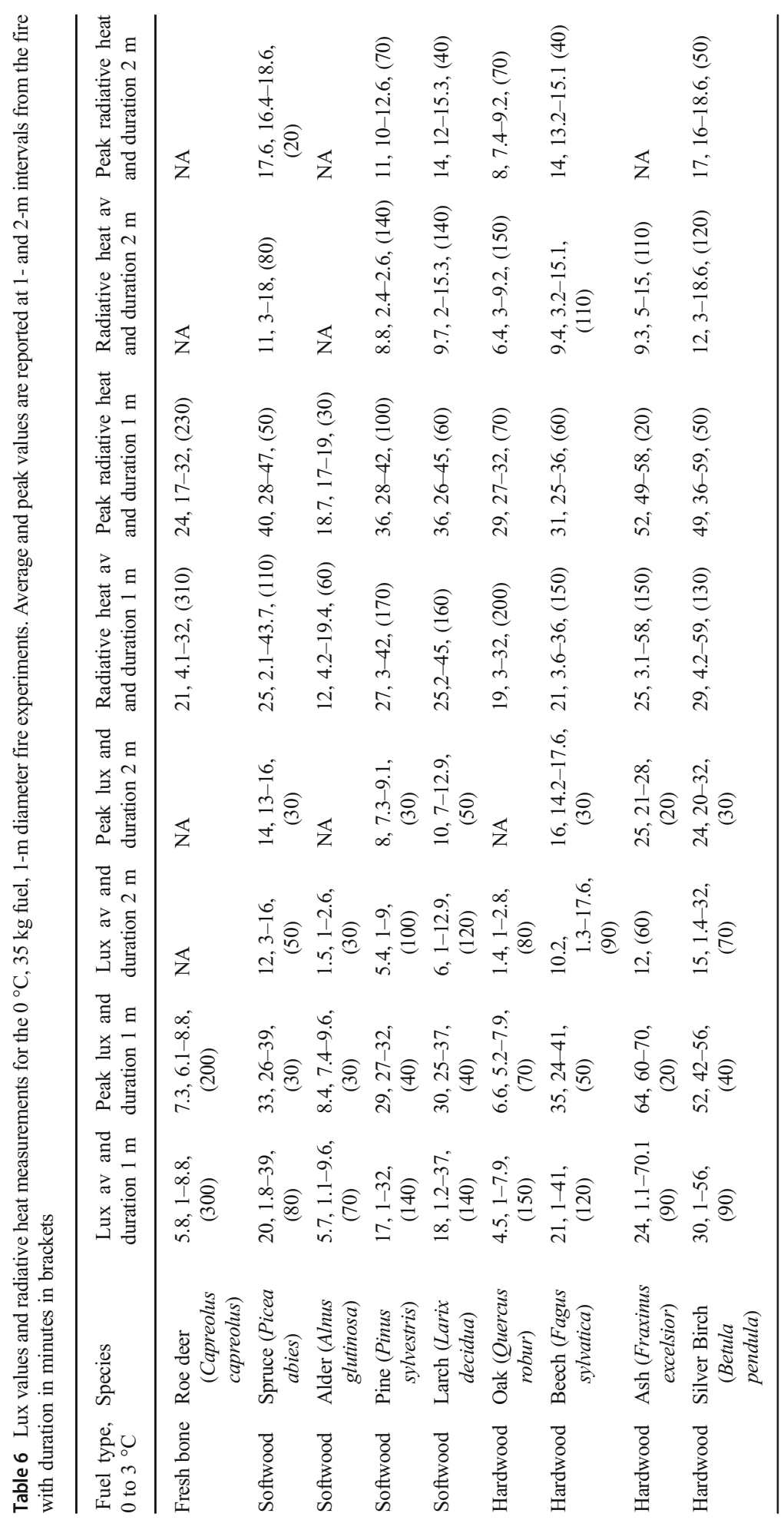




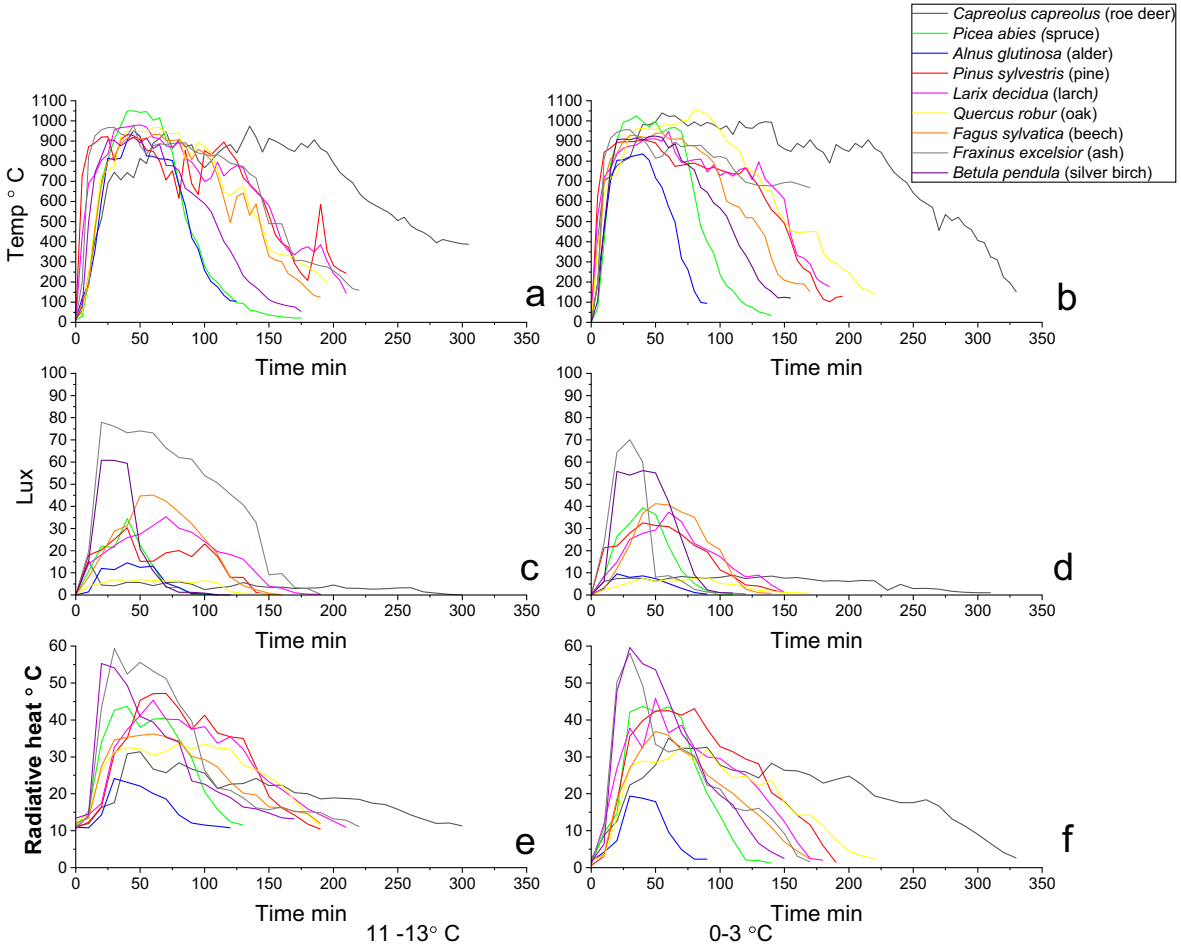

Fig. 3 Temperature (a, b), lux value (c, d) and radiative heat (e, f) measurements of the experimental $35 \mathrm{~kg}$ fuel, 1-m diameter fires for the 11 to $13{ }^{\circ} \mathrm{C}$ and 0 to $3{ }^{\circ} \mathrm{C}$ ambient air temperature ranges, respectively

\section{7 kg, 30-cm Diameter Fire Experiments}

\section{Lux Values}

The lux values for the $7 \mathrm{~kg}$ experiments are presented in Table 7 and are plotted along with temperature and radiative heat measurements in Fig. 4(a-c). Due to these being much smaller deposits using smaller amounts of fuel, measurements were taken at 70-cm distance from the fire only. Highest lux values were recorded for Betula, Fraxinus and Fagus, and the lowest for fresh bone and Quercus. The other species of wood all showed intermediate values. These results do however differ from the first two $35 \mathrm{~kg}$ experiments, in that Fagus previously yielded intermediate values and Alnus low values. The longest durations of luminosity were recorded for fresh bone, Quercus, Fagus and Larix. Little difference was recorded between the other types of fuel.

\section{Radiative Heat Measurements}

Average and peak values are presented in Table 7 and results are plotted in Fig. 4(c). The highest radiative heat measurements, although ca. $5{ }^{\circ} \mathrm{C}$ lower than the previous experiments, were recorded for Betula and Fraxinus. The longest duration of heating was recorded for fresh bone, Pinus, Fraxinus and Quercus. Little difference was observed in duration of heating for the other species of wood. 


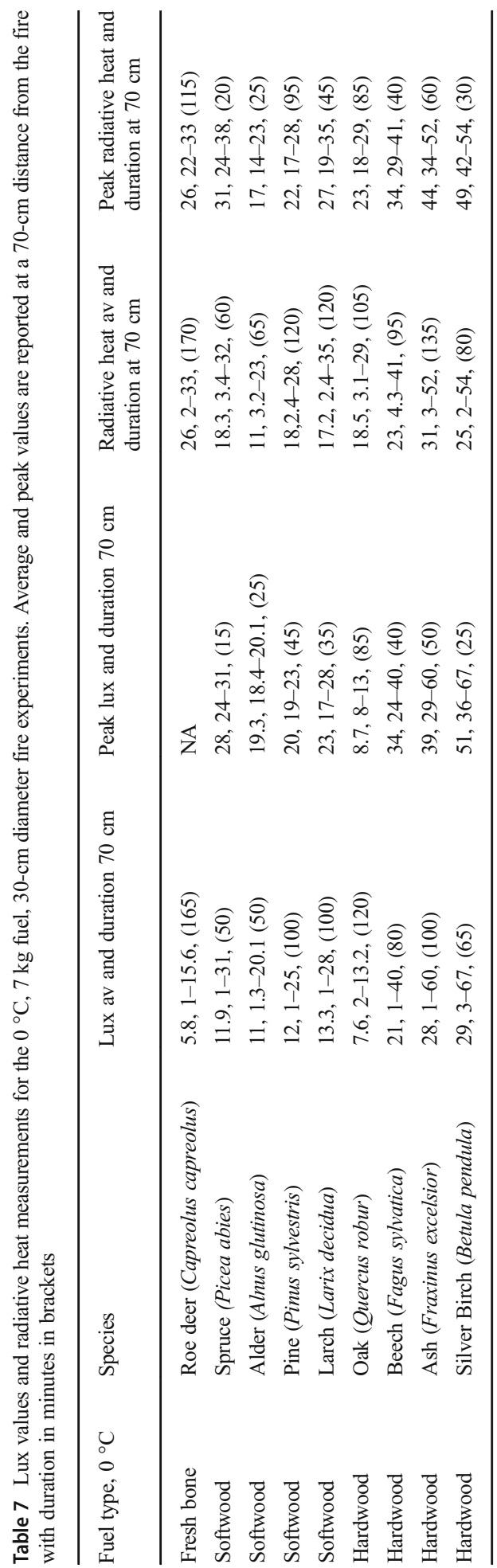



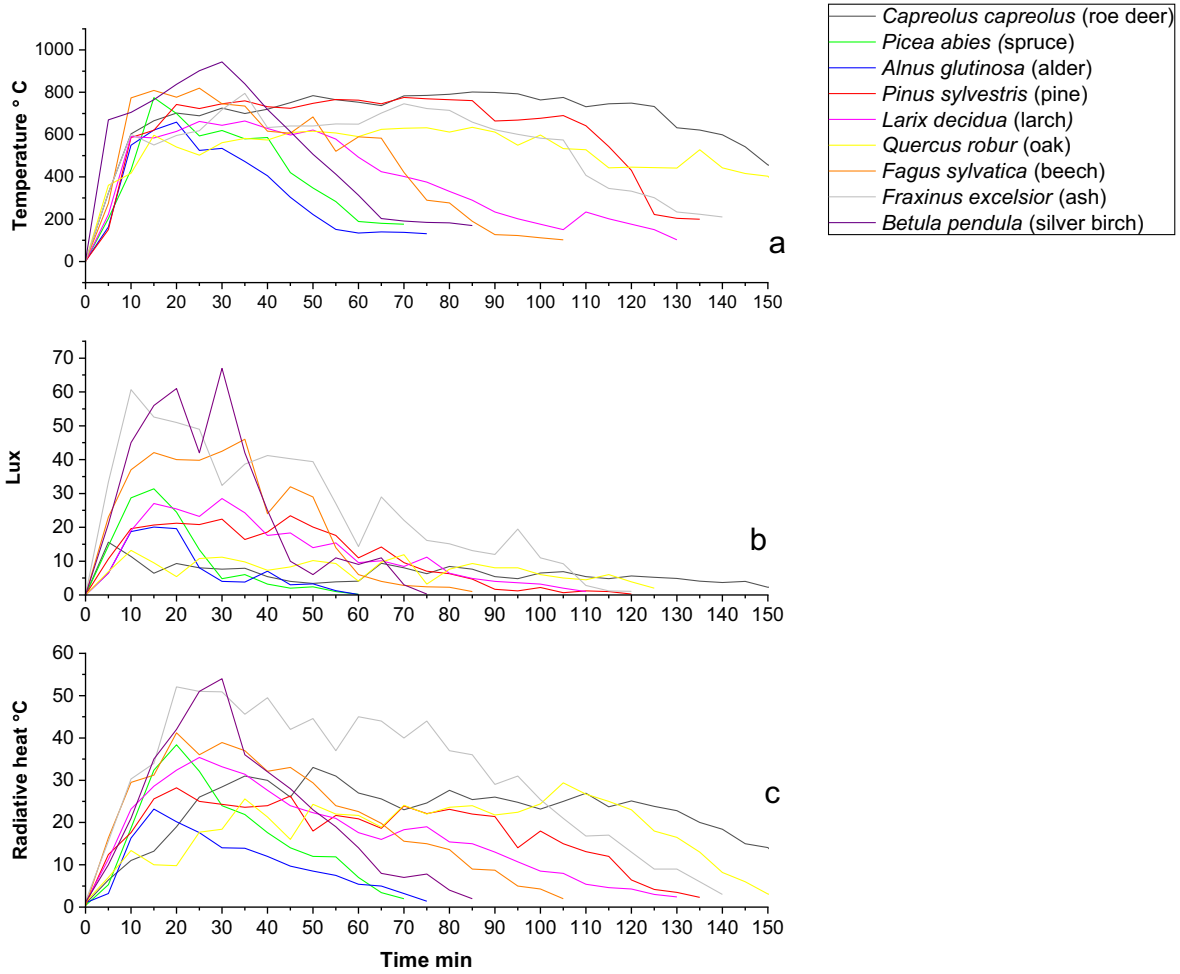

Fig. 4 Temperature (a), lux value (b) and radiative heat (c) measurements of the $7 \mathrm{~kg}$ fuel, 30-cm diameter experimental fires at an ambient air temperature of $0{ }^{\circ} \mathrm{C}$

\section{Comparison of Calorific Value of the Individual Wood Species with Radiative Heat Output}

As the experiments were conducted in an outdoor setting, the radiative heat outputs were compared with those of published data on the calorific value of the different wood species in order to provide baseline data of known combustion properties (see Fig. 5). Calorific value is not available for fresh animal bone. However, a calorific value of ca. $1500 \mathrm{kcal} / \mathrm{kg}$ is reported for the human body without flesh by Théry-Parisot et al. (2005). When compared with wood, $4000-4500 \mathrm{kcal} / \mathrm{kg}$ is much lower (Théry-Parisot et al. 2005). Calorific value of the same wood species can vary according to the method used, so data here is compiled from one source using the same method (Amy 1991). No data on Larix decidua was published in this paper, so the calorific value for Larix decidua is from Aniszewska and Gendek (2014).

The calorific values for the individual wood species are expressed in $\mathrm{MJ} / \mathrm{kcal}$, which represent the LHV, and range from 17.58 to 18.27 (see Table 8). Figure 5 plots of the calorific value for the different wood species compared with radiative heat output. When compared with the experimental results, the baseline data for the different wood species are broadly similar to those of the outgoing radiant heat. However, there is one notable 


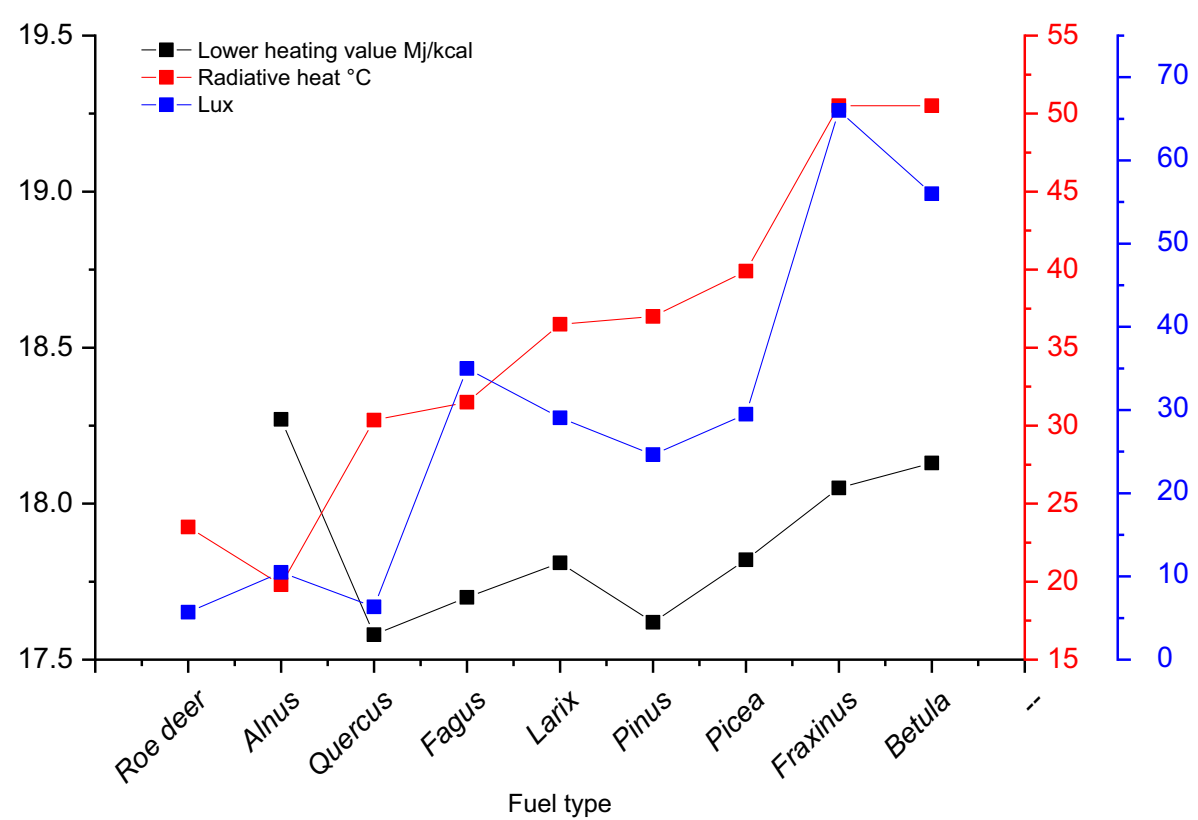

Fig. 5 Comparison of fuel calorific values in $\mathrm{MJ} / \mathrm{kcal}$, with lux and radiative heat values in ${ }^{\circ} \mathrm{C}$

exception, Alnus glutinosa, which has a much higher calorific value relative to radiant heat output. There are also some minor variations between the two data sets. For example, although Fraxinus has a higher LHV than Quercus, Fagus, Picea and Pinus, it has a lower LHV than that of Betula. However, when comparing results of radiative heat output, Fraxinus still yields higher temperature measurements than the aforementioned species but has very similar values in degrees Celsius to that of Betula. Pinus has a calorific value slightly higher than that of Quercus, but lower than that of Larix, Fagus and Picea. However, its radiant heat output is more similar to that of Larix and Picea. Fresh bone has a low radiative heat output, and if its calorific value is similar to that of a human body, it would also be expected to have a low calorific value. There are no published data on lumen values for different types of fuels with which to compare the experimental data.

Table 8 Calorific, lux and radiative heat values for the different wood species. The lux and radiative heat values were combined using data in Tables 5, 6 and 7 and then averaged

\begin{tabular}{llllc}
\hline Fuel type & Species & Calorific value & Radiative heat & Lux \\
\hline Fresh bone & Roe Deer (Capreolus capreolus) & NA & 23.5 & 5.7 \\
Softwood & Spruce (Picea abies) & 17.82 & 39.9 & 29.5 \\
Softwood & Alder (Alnus glutinosa) & 18.27 & 19.8 & 10.5 \\
Softwood & Pine (Pinus sylvestris) & 17.62 & 37 & 24.65 \\
Softwood & Larch (Larix decidua) & 17.81 & 36.5 & 29.05 \\
Hardwood & Oak (Quercus robur) & 17.58 & 30.35 & 6.35 \\
Hardwood & Beech (Fagus sylvatica) & 17.7 & 31.5 & 29.05 \\
Hardwood & Ash (Fraxinus excelsior) & 18.05 & 50.5 & 66 \\
Hardwood & Silver Birch (Betula pendula) & 18.13 & 50.5 & 56 \\
\hline
\end{tabular}




\section{Discussion}

\section{Summary of Results}

The purpose of this study was to examine variability in the combustion properties of wood and fresh bone, with regard to intensity of luminosity and outgoing radiative heat, and to examine whether these differences are considerable enough to have potentially affected choices of fuel in the Palaeolithic, if heat and light were the objectives of a fire. The second objective was to examine whether differences in ambient temperature could further affect choices of fuel in terms of seasonality. No previous experiments have been undertaken in Palaeolithic research in this regard. The experiments were conducted in an outdoor setting using different-sized deposits and amounts of fuel. In order to provide a degree of internal validity to these experiments, strict controls were in place regarding consistency of the size and shape of the deposits, the amount of fuel, moisture content and size of the logs (10$\mathrm{cm}$ diameter and $20-\mathrm{cm}$ length), and in the monitoring of background conditions, like windspeed, ambient temperature and humidity. Three different experimental series comprising of nine experiments each were performed: 1-m diameter fires consisting of $35 \mathrm{~kg}$ of fuel in ambient air temperatures between 11 and $13{ }^{\circ} \mathrm{C}$, repeated at ambient temperatures of 0 to $3{ }^{\circ} \mathrm{C}$ and then a third series of $30-\mathrm{cm}$ diameter fires using $7 \mathrm{~kg}$ of fuel at an ambient temperature of $0{ }^{\circ} \mathrm{C}$. It is noted that these results are applicable in an open-air setting only, and that results could differ in terms of how the light and heat properties of different sources of fuel could be experienced within shelters, caves and rock shelters. It should also be noted that changes in the size and shape of both the deposit and the fuel (i.e. shape and size of $\operatorname{logs}$ ) would undoubtedly introduce variability into the results. Differences in the average moisture content of the fuel between some of the experiments may also have introduced some variation into the results. It must be further considered that the addition of $5.5 \mathrm{~kg}$ of Betula pendula to the fresh bone fire could have affected the duration of the fire and light/heat properties. Although, as Betula pendula has both a high lux and radiative heat output, if the addition of the extra fuel had affected the results, an increase would have been expected for the bone fire, which appears not to be the case. Different species not tested here with specific burning qualities could yield further insights, e.g. Maloideae (Sorbus, Malus and Cratae$g u s$ ) or the fresh bones of animals larger than roe deer. It is also likely that the thermal properties of greenwoods, driftwoods and deadwoods of the same species would differ when compared with seasoned dried logs.

The author acknowledges that conducting these experiments in an outdoor setting may have introduced other variables which could have affected the results (e.g. differences in air movement) and that the testing of both the light and radiant heat outputs of different types of fuel is now necessary under more controlled laboratory conditions. With that said, the results of these experiments were in general reproducible on different size deposits using different amounts of fuel. However, some variability was introduced to the results with the inclusion of the smaller fires. The results of these experiments show that there is notable variability in the combustion properties of different types of fuel when it comes to intensity of luminosity and radiative heat output. 


\section{Comparison of Experimental Data with Calorific Value}

When comparing results from the experimental data set with the calorific values for the wood species, some of the results appear to run contrary to the baseline data, especially Alnus and, to a lesser degree, Pinus and Fraxinus. These differences could be the result of two factors. The first is that testing experimentally in an outdoor setting has introduced variability into some of the results not accounted for by measuring background wind speed, humidity and ambient temperature (e.g. air circulation). The second is that there are differences between radiant heat output and calorific value. Whilst calorific value provides a measure of energy emitted under laboratory conditions, it does not provide a measure of how that heat is transferred to the surrounding environment based on factors outlined in the 'Combustion Properties of Fuels and Transfer of Heat' section, although some of the results do appear to be similar to calorific value. The density of wood effects the speed of burning, which is also likely to determine the speed by which flames rise and fall, thereby affecting the size of the flames produced and thus radiant heat output at distance from the fire.

In terms of the luminosity properties of the different wood species and bone, there are no baseline data with which to compare the experimental results. With that said, it has previously been suggested that coniferous woods (i.e. softwoods) would yield strong and durable light properties due to a combination of wood density, molecular arrangement and resin content (Théry-Parisot and Thiebault 2005). In these experiments, consistency in the luminosity properties of the different coniferous woods Pinus, Larix and Picea was observed. These species all yielded intermediate light properties across all the experiments. The greatest variability observed for both luminosity and radiant heat output was for the angiosperms, or hardwood species. This variability may be the result of differences in wood densities, varied lignin contents and chemical composition and would require further testing under more standardised laboratory conditions. Differences in outgoing radiant heat in the angiosperms could be linked to differences in speed of burning and flame height. For example, although fresh bone may have a much lower calorific value than that of Quercus, it appears to have a similar radiant heat output. This could perhaps be explained by the fact that fresh bone produces a larger flame. Théry-Parisot et al. (2005) report the production of large durable flames from experimental bone fires. The larger surface area of the flame may compensate for a lower calorific value by transferring more heat to the surrounding environment than species with a higher calorific value, but weaker flame production such as Quercus robur.

It has been suggested that the calorific value varies little between individual wood species. However, when the combustion properties of different types of fuel are examined in the context of outgoing radiative heat, the differences observed in degrees Celsius appear to be notable between some of the wood species. For example, a $30{ }^{\circ} \mathrm{C}$ difference was observed between Quercus robur and Betula pendula, and a $20{ }^{\circ} \mathrm{C}$ difference between Pinus sylvestris and Betula pendula.

\section{Lux}

Notable differences are apparent in the lux values, which fall into three categories: high, intermediate and low in the current data set. The lux data also gave good reproducibility 
in terms of the repeat experiments, 11 to $13{ }^{\circ} \mathrm{C}$ and 0 to $3{ }^{\circ} \mathrm{C}$, and between the large $1 \mathrm{~m}$ versus smaller $30 \mathrm{~cm}$ fires. However, Alnus and Fagus both yielded higher lux values during the $30-\mathrm{cm}$ diameter fire experiments.

Whilst Betula and Fraxinus gave the highest lux values across all experiments, duration of lux is also important, as less fuel is then required to maintain light for longer periods. Betula and Picea both give higher lux values than, for example fresh bone or Quercus. However, both are fuels that burn out very rapidly relative to other fuels in the data set. In this regard, Fraxinus appeared to be able to maintain high levels of light for the longest period. Pinus yielded intermediate luminosity with a long duration in both the 35 and $7 \mathrm{~kg}$. Larix and Fagus also yielded intermediate to high lux values and a long duration of luminosity across all experiments. Fuels that maintain strong and durable light within the current data set are, therefore, Fagus, Larix, Fraxinus and Pinus or fresh bone, and Alnus and Quercus for low light duration. If a strong light was required, or light for larger group sizes, then wood is far more efficient than fresh bone in terms of intensity of luminosity. If a strong light was the intended outcome of a fire, then it is unlikely that either fresh bone or Quercus would be selected as a fuel for this purpose unless no other sources of fuel were immediately available. Conversely, fuels that emit low lux values (e.g. fresh bone or Quercus) may give less visibility at the landscape scale and thus would be less likely to attract attention on the landscape from afar should this also be desirable. Alnus also yields a low light; however, it is a very smoky wood and thus would also attract attention. Conversely, fuels that emit strong light and/or a lot of smoke could be used to signal at a landscape scale. Fuels that emit a lot of smoke could also be used to repel biting insects.

\section{Radiative Heat}

Heat is transferred to the surrounding environment via similar processes as those for light; therefore, the results of the radiative heat experiments are broadly similar to those of intensity of luminosity. The highest radiative heat measurements were recorded for Fraxinus and Betula. However, it is worth noting that these are extremely high temperatures (in excess of $50{ }^{\circ} \mathrm{C}$ ) with at times substantial duration (e.g. $70 \mathrm{~min}$ Fraxinus $35 \mathrm{~kg}, 11$ to $13{ }^{\circ} \mathrm{C}$ ) fire. Like light, if warmth was the intended purpose of a fire, fuels that give a longer duration of heat would be the most efficient as they require smaller amounts to provide warmth for longer. In relation to the different-sized experiments, the most fuels that yielded the longest and most durable heat were fresh bone, Quercus, Larix, Pinus, Fagus and Fraxinus. As sources of fuel, fresh bone, Quercus and Alnus emitted the lowest radiative heat in the current data set, but except for Alnus, give long duration of both flame and heat. Fuels that emit lower radiative heat $\left(20\right.$ to $\left.32{ }^{\circ} \mathrm{C}\right)$ may be more useful for tasks that require being in closer contact with a fire, as these allow direct contact with the flames. In terms of both light and heat outputs, and taken across all experiments, Fraxinus, Pinus, Larix and Fagus appear to provide both longer and higher levels of light and heat. If low levels of light and heat were the intended purpose, then Quercus and fresh bone could be selected. Different types of fuels could also be combined to maximise heat and/or light in relation to duration of the fire. For example, fresh bone and Quercus both give a long, slow, steady burn and heat. However, if used in combination with smaller amounts of fuel with higher lux/radiative heat outputs, e.g. Pinus continuously added to the fire, then the 
different thermal properties could be exploited in combination to maximise either heat or light.

As stated above, the second objective of these experiments was to test whether changes in ambient temperature could further affect choices of fuel with regard to their heat properties (i.e. seasonality or warmer and colder periods). These results are more applicable to seasonal choices of fuel. It is suggested here that fuels that emit very high radiative heat would be less efficient at colder temperatures (e.g. Betula and Fraxinus) for the simple reason that the heat is too high to provide usable heat for a significant duration of the fire, as it is too hot to stay close to the fire. This simply relates to the way heat is experienced at lower temperatures. When ambient temperatures are warmer (i.e. $11{ }^{\circ} \mathrm{C}$ ), it is possible to step back from the fire and still use the outgoing heat to stay warm whilst the peak temperatures of hotter fuels reduce to more usable heat (e.g. Fraxinus). When temperatures are lower, stepping back to a distance of $1 \mathrm{~m}$ area significantly reduces the benefits of radiative heat from the fire because of lower temperatures (i.e. effects such as windchill greatly outweigh the benefits conferred by heat). Therefore, in relation to the current data set, it is suggested that fuels that emit low to intermediate heat would be more efficient at colder winter temperatures in terms of warmth, as these fuels allow you to stay closer to the fire for the full duration. With that said, not all fires in the past would have been built as flaming fires; glowing fires could be used to reduce heat output from some fuels (e.g. Betula and Fraxinus) at colder temperatures. Across the 0 to $3{ }^{\circ} \mathrm{C} 1-\mathrm{m}$ diameter and $0{ }^{\circ} \mathrm{C} 30-\mathrm{cm}$ diameter experiments, fuels that gave the longest duration of burning in terms of warmth were found to be fresh bone, Quercus, Picea, Pinus, Larix and Fagus. It must be considered that these experiments only account for a $10{ }^{\circ} \mathrm{C}$ drop in temperature, and it is likely that with a further decrease in temperature (e.g. $-40{ }^{\circ} \mathrm{C}$ ), fuels that emit intermediate temperatures like Picea, Pinus, Larix and Fagus would provide greater warmth at colder temperatures. Fresh bone appears to be more common at sites in colder periods, although it appears in more temperate climates, as well. However, it has a low luminosity and low radiative heat. It is therefore unlikely that bone would be selected over wood for its thermal qualities in colder periods, unless its use was in response to an immediate need for fuel, e.g. (Théry-Parisot et al. 2005).

The main point to be drawn from these experiments is that considerable variation exists in the thermal properties of wood and fresh bone and between individual species of wood. The differences in these combustion properties could have affected choices of fuel amongst Palaeolithic populations, should variation in levels of light and/or heat be required for the intended purpose of a fire. These choices could potentially be further influenced by seasonality and between warmer and colder periods.

\section{Archaeological Implications}

Examining the combustion properties of different types of fuel could have significant implications for archaeologists when considered in relation to seasonal exploitation or purposes that require varying levels of light, heat and duration of burning. At the midto-northern latitudes, where the effects of seasonality on heat and light were most pronounced, the ability to maximise heat and light could confer a behavioural advantage to hunter-gatherer populations. It is not suggested here that species selection is more important than the state of the wood as a fuel selection criterion, or that prehistoric 
hunter-gatherers are selecting fuels according to their burning properties from the landscape. What is suggested, however, is that where a range of different types of fuels are being used or a number of different species, if their burning properties are variable, then it may be that those differences could be exploited for different tasks or purposes within a wider fuel management strategy. This may include the speed of burning (fast or slow), or whether the people were using fuels with varying degrees of outgoing radiative heat or light in different ways, inside or outside of housing structures or within caves and rockshelters. As Delhon (2018) cautions, there is no reason to think that Palaeolithic populations were not practising taxonomic selection given the wider acceptance of all the environmental socio-cultural factors affecting fuel management strategies in this period.

The intention here is to provide a reference database that can be considered within a wider context that includes all the factors discussed below. What this paper shows is that the differences can be considered notable enough in terms of light and heat to have potentially affected choices of fuel. Identifying whether light or heat was the intended purposes of a fire based on fuel selectivity is in reality much more complex. If Palaeolithic populations, or any prehistoric hunter-gatherers, were practising taxonomic selection in relation to these issues, then this would have to be considered within a wider framework encompassing environmental, seasonal, site function and patterns of mobility and cultural factors, the latter being the most difficult to discern in Palaeolithic research. Previous studies concerning fuel use by prehistoric populations/contemporary hunter-gatherers highlight the importance of the many parameters than can influence fuel management strategies within a given landscape (Asouti and Austin 2005; Kabukcu 2017; Henry et al. 2018; Pryor et al. 2016; Théry-Parisot 2001; 2002a, b). A given population can only select fuel from what is available on a landscape, both in terms of species and the condition of the fuel, i.e. whether it is dry, green, dead or rotten in the case of wood, or fresh or dry in the case of bone (Théry-Parisot 2001; 2002a, b). Selection can be further influenced by site function; for example, in temporary camps where there is a more immediate need for fuel, there may be less fuel selectivity than is practised at sites of longer term occupations (Théry-Parisot et al. 2005). Recent work on northern hunter-gatherer groups suggests that the degree of fuel selectivity is often correlated to the degree of hearth specialisation and that campfires tend to be fed with the most readily available wood regardless of task (Henry et al. 2018). Seasonality, or temporal availability, can further affect fuel selection in terms of warmth. The Ingalik are known to select spruce over willow and poplar in the winter due to the superior thermal qualities of spruce (Théry-Parisot 2002a, b). However, seasonality can also affect what fuel is selected, as well, especially in terms of moisture content and deadwood availability. Cultural practises can also determine strategies of fuel management, with some fuels being avoided due to cultural biases (Delhon 2018; Henry et al. 2018; Théry-Parisot 2002a, b). Importantly, the ethnographic record demonstrates that both the state of the wood and the combustion properties of species are being considered in relation to fuel selection by some contemporary hunter-gatherers when it comes to aspects of hearth function. However, this highlights the importance of all the above factors when examining patterns of fuel selectivity amongst Palaeolithic populations (e.g. Delhon 2018). Little is currently known regarding the circumstances in which fire use arose in an evolutionary context and how and when the various benefits of human fire-related behaviours became important. It is possible that fuel selection 
criterion for Palaeolithic hunter-gatherer populations could have differed according to environmental context, this being driven by different ecological pressures. In this case, for example, selection of fuel in relation to heating properties, and also seasonal changes in types of fuel, would be predicted for groups inhabiting environments with greater extremes in temperature and more heightened effects of seasonality. In effect, seasonal choices of fuel should have a positive correlation with latitude. Examining the combustion properties of fuels via experimental archaeology can potentially provide a means towards identifying certain aspects of past human fire-related behaviours in relation to the thermal transfer of energy with regard to fuel selectivity.

\section{Conclusion}

Not all species of wood and types of fuel burn the same way. Variability exists in the amount of ash and smoke produced, along with differences in the speed of burning and outgoing luminosity and radiant heat. Differences in these combustion properties can be used for different purposes, as is noted by recent ethnoarchaeological research (Henry et al. 2018). These experiments show that considerable differences are apparent in both intensity of luminosity and radiative heat outputs between wood and fresh bone, and between individual species of wood. Further differences exist in the way outgoing heat from fires can be experienced from different types of fuel at colder temperatures. These data represent a step forward in examining the combustion properties of different types of fuel with regard to the thermal transfer of energy. With regard to selecting the varying heat and light properties of fuels in relation to tasks, the following suggestions are made:

1. With regard to heat and light, there are no good or bad fuels. All fires regardless of the type of fuel used will provide light and warmth.

2. Significant differences do exist in the both the amount and duration of that heat/ light from different types of fuels which may make some fuels more efficient than others for specific tasks where varied amounts of heat and or light might be required.

3. In terms of warmth, fuels that emit very high radiative heat (e.g. Betula and Fraxinus) are less efficient at colder temperatures than those that emit intermediate/lower radiative heat, as they do not provide usable heat for a significant portion of the fire.

4. Fuels with higher levels of radiative heat may have been beneficial for heating larger spaces such as caves.

5. Fuels with lower radiative heat could have been beneficial for heating smaller spaces such as housing structures.

6. Fuels that emit higher lux and radiative heat measurements would be more efficient for larger group sizes.

7. Fuels that emit lower radiative heat, such as fresh bone, Alnus and Quercus, are more efficient for tasks that require closer contact with the fire/flames, since the outgoing radiative heat is low despite the combustion temperatures of the actual fire/flames remaining high.

8. Fuels that emit lower light levels, e.g. fresh bone and Quercus, could be selected to avoid attracting attention on the landscape. 
Further experiments are being conducted to examine the thermal properties of greenwoods, driftwoods, rottenwoods and deadwoods of the species examined above to make the data more relatable to prehistoric fuel use and to expand the range of fuel sources. It is likely that differences in the amount and duration of light and heat emitted between the wood species relate to variations in the anatomical structure and chemical composition of the wood. A systematic review of uses of fuel amongst contemporary hunter-gatherer groups could explicitly test some of the assumptions laid out in this paper, namely that fuel selection with regard to light and especially heat could be associated with specific environments and with the heightened effects of seasonality. With regard to selection of fuels in relation to specific combustion properties, future work could examine potential changes/increases in the use of single species or particular types of fuel between warmer and colder periods and also by comparing the combustion properties of fuels where multiple species/types or states of fuel are found.

Acknowledgements I would like to thank Anthony Sinclair and Ceren Kabucku, University of Liverpool, for their comments on this manuscript. Thanks also to participants of the Palaeofire workshop, held at the University of Reading (23/02/2018) where discussions took place on the possibility of latitudinal trends in the use of fire. Thanks is also given to Jason Hall and Peter Gethin, University of Liverpool, and to the two anonymous reviewers.

\section{Compliance with Ethical Standards}

Conflict of Interest The author declares that she has no conflict of interest.

Open Access This article is licensed under a Creative Commons Attribution 4.0 International License, which permits use, sharing, adaptation, distribution and reproduction in any medium or format, as long as you give appropriate credit to the original author(s) and the source, provide a link to the Creative Commons licence, and indicate if changes were made. The images or other third party material in this article are included in the article's Creative Commons licence, unless indicated otherwise in a credit line to the material. If material is not included in the article's Creative Commons licence and your intended use is not permitted by statutory regulation or exceeds the permitted use, you will need to obtain permission directly from the copyright holder. To view a copy of this licence, visit http://creativecommons.org/licenses/by/4.0/.

\section{References}

Amy, L. (1991) Les bases physico-chimiques de combustion de la cellulose et des matériaux ligneux, Cahier $\mathrm{N}^{\circ} 45 \mathrm{du}$ CTB (FCBA).

Aniszewska, M., \& Gendek, A. (2014). Comparison of heat of combustion and calorific value of the cones and wood of selected forest tree species. Forest Research Papers, 75, 231-223.

Asouti, E., \& Austin, P. (2005). Reconstructing woodland vegetation and its exploitation by past societies, based on the analysis and interpretation of archaeological wood charcoal macro-remains. Environmental Archaeology, 10(1), 1-18.

Aldeias, V. (2017). Experimental approaches to archaeological fire features and their behavioural relevance. Current Anthropology, 58, S191-S205.

Aldeias, V., Dibble, H. L., Sandgathe, D., Goldberg, P., \& McPherron, S. J. P. (2016). How heat alters underlying deposits and implications for archaeological fire features: a controlled experiment. Journal of Archaeological Science, 67, 64-79.

Badal, J., Villaverde, V., Zilhão, J. (2012) Middle Palaeolithic wood charcoal from three sites in South and West Iberia: biogeographic implications. In Badal, E.C., Y.; Macias, M.; Ntinou and M., Eds. Wood and charcoal. Evidence for human and natural history. Vol. 13, Valencia, Universitat de Valencia, pp.24-41 
Beresford-Jones, D. G., Johnson, K., Pullen, A. G., Pryor, A. J. E., Svoboda, J., \& Jones, M. K. (2010). Burning wood or burning bone? A reconsideration of flotation evidence from Upper Palaeolithic (Gravettian) sites in the Moravian Corridor. Journal of Archaeological Science, 37(11), 2799-2811.

Bennett, J. L. (1999). Thermal alteration of buried bone. Journal of Archaeological Science, 26, 1-8.

Bentsen, S. E. (2014). Using pyrotechnology: fire-related features and activities with a focus on the African Middle Stone Age. Journal of Archaeological Research, 22, 141-175.

Blasco, R., Rosell, J., Sañudo, P., Gopher, A., \& Barkai, R. (2016). What happens around a fire: faunal processing sequences and spatial distribution at Qesem cave (300 ka), Israel. Quaternary International, 398, 190-209.

Brown, K. S., Marean, C. W., Herries, A. I. R., Jacobs, Z., Tribolo, C., Braun, D., Roberts, D. L., Meyer, M. C., \& Bernatchez, J. (2009). Fire as an engineering tool of early humans. Science, 325, 859-862.

Canti, M., \& Linford, N. (2000). The effects of fire on archaeological soils and sediments: temperature and colour relationships. Proceedings of the Prehistoric Society, 66, 385-395.

Carrión, Y., Ntinou, M., \& Badal, E. (2010). Olea europaea L. in the North Mediterranean Basin during the Pleniglacial and the Early-Middle Holocene. Quaternary Science Reviews, 29, 952-968.

Carmody, R. N., \& Wrangham, R. (2009). The energetic significance of cooking. Journal of Human Evolution, 57, 379-391.

Costamagno, S., Théry-Parisot, I., Brugal, J. P., \& Guilbert, R. (2005). Taphonomic consequences of the use of bones as fuel: experimental data and archaeological applications. In T. O'Connor (Ed.), Biosphere to lithosphere: New studies in vertebrate taphonomy (pp. 51-62). London: Oxbow.

Delhon, C. (2018). Is choice acceptable? How the anthracological paradigm may hinder the consideration of fuel gathering as a cultural behaviour. Environmental Archaeology. https://doi.org/10.1080 /14614103.2018.1522783.

Cichocki, O., Knibbe, B., \& Tillich, I. (2014). Archaeological significance of the Palaeolithic charcoal assemblage from Krems-Wachtberg. Quaternary International, 351, 163-171.

Dussol, L., Elliot, M., \& Théry-Parisot, I. (2017). Experimental anthracology: evaluating the role of combustion processes in the representivity of archaeological charcoal records in tropical forests, a case study from the Maya lowlands. Journal of Archaeological Science: Reports, 12, 580-490.

Julia, C., Théry-Parisot, I., Fiorucci, G., Terral, J. F., \& Thibaut, B. (2014). Impact of post-depositional processes on charcoal fragmentation and archaeobotanical implications: Experimental approach combining charcoal analysis and biomechanics. Journal of Archaeological Science, 44(1), 30-42.

Goldberg, P., Dibble, H., Berna, F., Sandgathe, D., McPherron, S. J., \& Turq, A. (2012). New evidence on Neandertal use of fire: examples from Roc de Marsal and Pech de l'Azé IV. Quaternary International, 247, 325-340.

Gowlett, J. A. J. (2006). The early settlement of northern Europe: fire history in the context of climate change and the social brain. Comptes Rendus Palevol, 5, 299-310.

Gowlett, J. A., \& Wrangham, R. W. (2013). Earliest fire in Africa: towards the convergence of archaeological evidence and the cooking. Azania: Archaeol Res Afr, 48, 5-30.

Haesaerts, P., Borziac, I., Chekha, V. P., Chirica, V., Drozdov, N. I., Koulakovska, L., Orlova, L. A., Van der Plicht, J., \& Damblon, F. (2010). Charcoal and wood remains for radiocarbon dating Upper Pleistocene loess sequences in Eastern Europe and Central Siberia. Palaeogeography, Palaeoclimatology, Palaeoecology, 291, 106-127.

Henry, A., \& Théry-Parisot, I. (2014). From Evenk campfires to prehistoric hearths: charcoal analysis as a tool for identifying the use of rotten wood as fuel. Journal of Archaeological Science, 52, 321-336.

Herzog, N. M., Keefe, E. R., Parker, C., et al. (2016). What's burning got to do with it? Primate foraging opportunities in fire-modified landscapes. American Journal of Physical Anthropology, 159(3), 432-441.

Henry, A., Zavadskaya, E., Alix, C., Kurovskaya, E., \& Beyries, S. (2018). Ethnoarchaeology of fuel use in northern forests: towards a better characterization of prehistoric fire-related activities. Journal of Archaeological, Ethnographic and Experimental Studies., 10(2), 99-120.

Hoare S. (2019). The possible role of predator prey dynamics as an influence on early hominin use of burned landscapes. Evolutionary Anthropology. 28, 295-302https://doi.org/10.1002/evan.21807

Kabukcu, C. (2017). Identification of woodland management practices and tree growth conditions in archaeological fuel waste remains: a case study from the site of Çatalhöyük in Central Anatolia, Turkey. Quaternary International, 463(B), 282-297.

Mallol, C., Hernandez, C. M., Cabanes, D., Machado, J., Sistiaga, A., Perez, L., \& Galvan, B. (2013). Human actions performed on simple combustion structures: an experimental approach to the study of Middle Palaeolithic fire. Quaternary International, 315, 3-15. 
March, R. J., Lucquin, A., Joly, D., Ferreri, J. C., \& Muhieddine, M. (2014). Processes of formation and alteration of archaeological fire structure: complexity viewed in the light of experimental approaches. Journal of Archaeological Method and Theory, 21, 1-45.

Marquer, L., Ottoe, T., Nespoulet, R., \& Chiotti, L. (2010). A new approach to study the fuel used in hearths by hunter-gatherers at the Upper Palaeolithic site of Abri Pataud (Dordogne, France). Journal of Archaeological Science, 37(11), 2735-2746.

Mentzer, S. M. (2009). Bone as a fuel source: the effects of initial fragment size distribution. In Pp. (Ed.), Gestion des combustibles au Paleolithique et au Mesolithique: nouveaux outiles, nouvelles interpretations. Isabelle Théry-Parisot Sandrine Costamagno, and Auréade Henry (pp. 53-64). Oxford: Archaeopress.

Miller C.E., Conard N., Goldberg P., Berna F. (2010). Dumpling, sweeping and trampling: experimental micromorphological analysis of anthropogenically modified combustion features. In I. Théry-Parisot, L. Chabal, S. Costamagno (Eds.), The taphonomy of burned organic residues and combustion features in archaeological contexts, palethnologie, Proceedings of the Round Table, Valbonne, May 27-29 (2010), pp. 25-37.

Mourre, V., Villa, P., \& Henshilwood, C. S. (2010). Early use of pressure flaking on lithic artifact at Blombos Cave, South Africa. Science, 330, 659-662.

Parker, C. H., Keefe, E. R., Herzog, N. M., O'connell, J. F., \& Hawkes, K. (2016). The pyrophillic primate hypothesis. Evolutionary Anthropology, 25, 54-63.

Porraz, G., Texier, P. J., Archer, W., Piboule, M., Rigaud, J. P., \& Tribolo, C. (2013). Technological successions in the Middle Stone Age sequence of Diepkloof Rock Shelter, Western Cape, South Africa. Journal of Archaeological Science, 40, 3376-3400.

Preece, R., Gowlett, J. A. J., Parfitt, S. A., Bridgland, D., \& Lewis, S. (2006). Humans in the Hoxnian: habitat, context and fire use at beeches pit, West Stow, Suffolk, UK. Journal of Quaternary Science, 21, 485-496.

Pruetz, J. D., \& Herzog, N. M. (2017). Savanna chimpanzees at Fongoli, Senegal, navigate a fire landscape. Current Anthropology, 58, S337-S350.

Pryor, A. J. E., Pullen, A., Beresford-Jones, D. G., Svoboda, J. A., \& Gamble, C. S. (2016). Reflections on Gravettian firewood procurement near the Pavlov Hills, Czech Republic. Journal of Anthropological Archaeology, 43, 1-12.

Roebroeks, W., \& Villa, P. (2011). On the earliest evidence for habitual use of fire in Europe. Proceedings of the National Academy of Sciences of the United States of America, 108, 5209-5214.

Schmidt, P., Slodczyk, A., Lea, C., Davidson, A., Puaud, S., \& Sciau, P. (2013). A comparative study of the thermal behaviour of length-fast chalcedony, length-slow chalcedony (quartzine) and moganite. Physics and Chemistry of Minerals, 40(4), 331-340.

Schmidt, P., Paris, C., \& Bellot-Gurlet, L. (2016). The investment in time needed for heat treatment of flint and chert. Archaeological and Anthropological Sciences, 8(4), 839-848.

Shaw, J. D. (2008). Driftwood as a resource: modeling fuelwood acquisition strategies in the mid- to late Holocene Gulf of Alaska. University of Washington: Unpublished Doctoral Dissertation.

Shaw, J. D. (2012). Economies of driftwood: fuel harvesting strategies in the Kodiak archipelago. Etudes/Inuit/ Stud., 36(1), 63-88.

Steelandt, S., Bhiry, N., Marguerie, D., Desbiens, C., Napartuk, M., \& Desrosiers, P. M. (2013). Inuit knowledge and use of wood resources on the west coast of Nunavik. Canada. Etudes/Inuit/Studies., 37, 147-173.

Telmo, C., \& Lousada, J. (2011). Heating values of wood pellets from species. Biomass and Bioenergy, 35, 2634-2639.

Théry-Parisot, I. (2001). Économie des combustibles au Paléolithique. Expérimentation, anthracologie, taphonomie. Paris: D.D.A. CNRS-Editions.

Théry-Parisot, I. (2002a). Fuel management (bone and wood) during the lower Aurignacian in the Pataud rock shelter (Lower Palaeolithic, Les Eyzies de Tayac, Dordogne, France). Contribution of Experimentation. Journal of Archaeological Science, 29, 1415-1421.

Théry-Parisot I. (2002b). Gathering of firewood during the Palaeolithic, pp. 243-9 in Thiebault, S. (ed.), Charcoal analysis: methodological approaches, palaeoecological results and wood uses (BAR International Series 1063). Oxford: Archaeopress.

Théry-Parisot, I., \& Costamagno, S. (2005). Propriétés combustibles des ossements. Gallia Préhistoire, 47, 235-254.

Théry-Parisot, I., Costamagno, S., Brugal, J. P., Fosse, P., \& Guilbert, R. (2005). The use of bone as fuel during the Palaeolithic: experimental study of bone combustible properties. In J. Mulville \& A. Outram (Eds.), The zooarchaeology of fats, oils, milk, and dairying. Oxford: Oxbow. 
Thery-Parisot, I., \& Thiebault, S. (2005). Le pin (Pinus sylvestris): préférence d'un taxon ou contrainte de l'environnement? Étude des charbons de bois de la Grotte Chauvet. Bulletin de la Société préhistorique française, 102, 60-75.

Théry-Parisot, I., Chabal, L., \& Chrzavzez, J. (2010). Anthracology and taphonomy, from wood gathering to charcoal analysis: a review of the taphonomic processes modifying charcoal assemblages, in archaeological contexts. Palaeogeography, Palaeoclimatology, Palaeoecology, 291(1/2), 142-153.

Vidal-Matutano, P., Henry, A., \& Théry-Parisot, I. (2017). Dead wood gathering among Neanderthal groups: charcoal evidence from Abric del Pastor and El Salt (Eastern Iberia). Journal of Archaeological Science, $80,109-121$.

Théry-Parisot I., Henry A. (2012). Seasoned of green? Radial cracks analysis as a method for identifying the use of green wood as fuel in archaeological charcoal. Journal of Archaeological Science 39(2) DOI: * https://doi.org/10.1016/j.jas.2011.09.024.

Uzquiano, P. (2014). Wood resource exploitation by Cantabrian Late Upper Palaeolithic groups (N Spain) regarding MIS 2 vegetation dynamics. Quaternary International, 337, 154-162.

Villa, P., Bon, F., \& Castel, J. C. (2002). Fuel, fire and fireplaces in the Palaeolithic of western Europe. Review of Archaeology, 23(1), 33-42.

Williams, F. A. (1982). Urban and wildland fire phenomenology. Progress in Energy and Combustion Science, $8,317-354$.

Wrangham, R., \& Carmody, R. (2010). Human adaptation to the control of fire. Evolutionary Anthropology, 19, 187-199.

White, R., Mensan, R., Clark, A. E., Tartar, E., Marquer, L., Bourrillon, R., Goldberg, P., Chiotti, L., Cretin, C., Rendu, W., Pike-Tay, A., \& Ranlett, S. (2017). Technologies for the control of heat and light in the Vezere Valley Aurignacian. Current Anthropology, 58(16), S288-S302.

Yravedra, J., \& Uzquiano, P. (2013). Burnt bone assemblages from El Esquilleu cave (Cantabria, Northern Spain): deliberate use for fuel or systematic disposal or organic waste. Quaternary Science Reviews, 68, $175-190$.

Publisher's Note Springer Nature remains neutral with regard to jurisdictional claims in published maps and institutional affiliations. 